\title{
Larval fish assemblages and particle back-tracking define latitudinal and cross-shelf variability in an eastern Indian Ocean boundary current
}

\author{
D. Holliday ${ }^{1, *}$, L. E. Beckley ${ }^{1}$, N. Millar ${ }^{1}$, M. P. Olivar ${ }^{2}$, D. Slawinski ${ }^{3}$, M. Feng ${ }^{3}$, \\ P. A . Thompson ${ }^{4}$ \\ ${ }^{1}$ School of Environmental Science, Murdoch University, 90 South St, Murdoch 6150, Western Australia, Australia \\ ${ }^{2}$ Institut de Ciènces del Mar (CSIC), Passeig Marítim 37-49, Barcelona 08003, Spain \\ ${ }^{3}$ CSIRO Marine and Atmospheric Research, Private Bag 5, Wembley, Western Australia 6913, Australia \\ ${ }^{4}$ CSIRO Marine and Atmospheric Research, GPO Box 1538, Hobart, Tasmania 7701, Australia
}

\begin{abstract}
Empirical and modelled data were used to examine the influence of the Leeuwin Current on larval fish assemblages along the Western Australian continental shelf and adjacent eastern Indian Ocean $\left(22^{\circ} \mathrm{S}-34^{\circ} \mathrm{S}\right)$ during the late austral autumn. Larval fish assemblages, comprising > 200 taxa from 114 neritic and oceanic teleost families, displayed significantly distinct latitudinal and cross-shelf variability, which was linked to meso-scale features of the Leeuwin Current, specifically anticyclonic eddies. Results of Lagrangian particle back-tracking showed good connection between the shelf and a developing eddy situated at $27^{\circ} \mathrm{S}$; connectivity was highest in the $0-20 \mathrm{~m}$ depth stratum where $>80 \%$ of the particles entering the eddy were derived from the shelf. This was supported by the high abundance (mean: 84 larvae $\mathrm{m}^{-2}$ ) of larval neritic taxa, especially small anchovy Engraulis australis larvae in the eddy. The lack of a significant difference in the size structure of these larvae between the shelf and eddy indicated continuous connection between these waters. In contrast, connectivity between the shelf and an older eddy further south was much lower ( $<40 \%$ of particles in the 0-20 m stratum) and the larval fish assemblage was dominated by meso-pelagic species. Further, the distribution of Myctophidae larvae (Diaphus spp.) highlighted areas of enhanced onshore transport in the south. The study has shown that, in the alongshore dominated Leeuwin Current system, cross-shelf transport can be similarly important in dispersal processes.
\end{abstract}

KEY WORDS: Leeuwin Current · Western Australia $\cdot$ Eddy $\cdot$ Lagrangian $\cdot$ Myctophidae Engraulidae

Resale or republication not permitted without written consent of the publisher

\section{INTRODUCTION}

Physical mechanisms that transport pelagic larvae along and across continental shelves are central to understanding larval dispersal and the connectivity between marine fish populations. Boundary current circulation is characterised by mesoscale processes such as meanders, filaments and eddies, which enhance shelf-ocean exchange (Csanady 1997). Strong spatial and temporal variability in larval fish assemblages over continental shelves is influenced by and reflects the scale of these oceanographic processes (e.g. Cowen et al. 1993, Franco et al. 2006, Lanksbury et al. 2005, Okazaki \& Nakata 2007, Keane \& Neira 2008, Muhling et al. 2008, Holliday et al. 2011). Recruitment variability of coastal teleost species has been linked to variability of the Gulf Stream (Hare et al. 1999), the Florida Current (Graber \& Limouzy- 
Paris 1997, Cowen 2002, Sponaugle et al. 2005) and the East Australian Current (Booth et al. 2007). Interannual variability of the anomalously poleward-flowing eastern boundary Leeuwin Current off the coast of Western Australia (Pearce 1991, Feng et al. 2003, Ridgway \& Condie 2004) is also linked to recruitment variability in several marine populations (Lenanton et al. 1991, Caputi et al. 1996, Caputi 2008, Feng et al. 2010), although the mechanism(s) driving this relationship are less well understood.

Within boundary current systems, alongshore transport is typically several orders of magnitude greater than cross-shelf velocities; for example, alongshore transport of the Gulf Stream was estimated to be 4-5 times greater than its cross-shelf flow (Hare et al. 1999). Pearce et al. (2006) estimated a cross-shelf velocity of $0.1 \mathrm{~m} \mathrm{~s}^{-1}$ off Western Australia that is an order of magnitude lower than the mean southward velocity of the Leeuwin Current. Recent observations, however, show that mesoscale perturbations of the current function to disrupt transport in the alongshore direction whilst enhancing cross-shelf exchange (Feng et al. 2010). Weller et al. (2011) reported a substantial reduction in velocity by $\sim 0.8 \mathrm{~m} \mathrm{~s}^{-1}$ of the current immediately south of a large anticyclonic eddy off southwestern Australia.

The mesoscale oceanography of boundary currents is reported to enhance mixing and cross-shelf exchange and this is reflected in a homogenous water mass and corresponding larval fish assemblage (e.g. Franco-Gordo et al. 2002, Keane \& Neira 2008). Auth (2008) found that processes operating in both the cross-shelf and alongshore directions were simultaneously important in structuring larval fish assemblages in the central and northern California Current region. Off southwestern Australia, Muhling et al. (2008) showed that the cross-shelf distributions of larval fish assemblages displayed the greatest variability in response to seasonal eddy formation. Weller et al. (2011) showed that the Leeuwin Current was increasingly energetic and highly variable in terms of its velocity and direction due to meso-scale perturbations and, combined, these processes are expected to have implications for the transport of planktonic biota and the connectivity between shelf and oceanic waters off the coast of Western Australia.

Feng et al. (2010) have identified several geographical regions of low and high retention of shelf waters off Western Australia that are related to ocean circulation and coastal geography. Areas of the continental shelf that experienced low retention were those that were exposed to high alongshore currents (particularly where the Leeuwin Current made considerable incursion over the shelf) and mesoscale eddies, both of which induce vigorous horizontal and vertical mixing. Holliday et al. (2011) showed that the larval fish assemblage of a developing anticyclonic eddy off southwestern Australia reflected its Leeuwin Current, shelf and oceanic source waters and that the Leeuwin Current was the primary pathway for the incorporation of larvae of neritic teleosts to the eddy. In certain situations, eddies can be responsible for significant variability in recruitment in fish and invertebrate populations as a result of eddy-induced offshore transport (e.g. Flierl \& Wroblewski 1985, Graber \& Limouzy-Paris 1997). Conversely, they can be important for the transport of larvae from spawning areas to nursery grounds (e.g. Hare et al. 2001, 2002).

The present study was part of an interdisciplinary shelf-scale survey during the late austral autumn of the Leeuwin Current over a $1500 \mathrm{~km}$ trajectory from latitudes $22^{\circ} \mathrm{S}$ to $34^{\circ} \mathrm{S}$ in the southeastern Indian Ocean. It details the response of larval fish assemblages to cross-shelf variability in the current, including the formation of 2 large anticyclonic eddies. The uniquely poleward-flowing Leeuwin Current is analogous to its western boundary current counterparts, the Agulhas Current and East Australian Current, where mesoscale variability similarly influences the distributions of larval fishes (e.g. Beckley \& Van Ballegooyen 1992, Suthers et al. 2011) Sampling was timed to coincide with the seasonal (austral autumn-winter) peak in Leeuwin Current transport and when the annual primary production cycle was nearing its peak (Thompson et al. 2011). We hypothesised that cross-shelf transport is enhanced by the mesoscale oceanography of the Leeuwin Current, such as the formation of anticyclonic eddies, and that the distributions of larval fishes of neritic and oceanic taxa would reflect the influence of these processes. It was also hypothesised that the strong southwards transport of the Leeuwin Current would weaken any latitudinal gradient in larval fish assemblages off the Western Australian coast. We examine larval fish assemblages from shelf and oceanic waters and provide a comparison of the larval distributions of an epipelagic coastal species and an oceanic, mesopelagic fish species, both of which are useful biological tracers of cross-shelf exchange. We also compared the empirical distributions of observed larval fish assemblages with results of regional-scale Lagrangian particle back-tracking to evaluate the cross-shelf connection between shelf waters and 2 anticyclonic eddies. 


\section{MATERIALS AND METHODS}

\section{Sample collection}

Larval fishes were sampled from shelf and offshore waters off Western Australia from $22^{\circ} \mathrm{S}$ to $34^{\circ} \mathrm{S}$ in the late austral autumn, May 2007. This study covered 13 cross-shelf transects at each degree of latitude with samples collected over the 50,300 and $2000 \mathrm{~m}$ isobaths, which represent inner shelf, shelf break and oceanic waters, respectively (Fig. 1).

Opportunistic sampling of an anticyclonic eddy (Fig. 2) located approximately $200 \mathrm{~km}$ offshore was undertaken along a seaward extension of the $31^{\circ} \mathrm{S}$ transect beyond the $2000 \mathrm{~m}$ isobath from 21 to 23 May 2007. Sampling of the eddy targeted specific locations, i.e. the seaward (west) perimeter, eddy

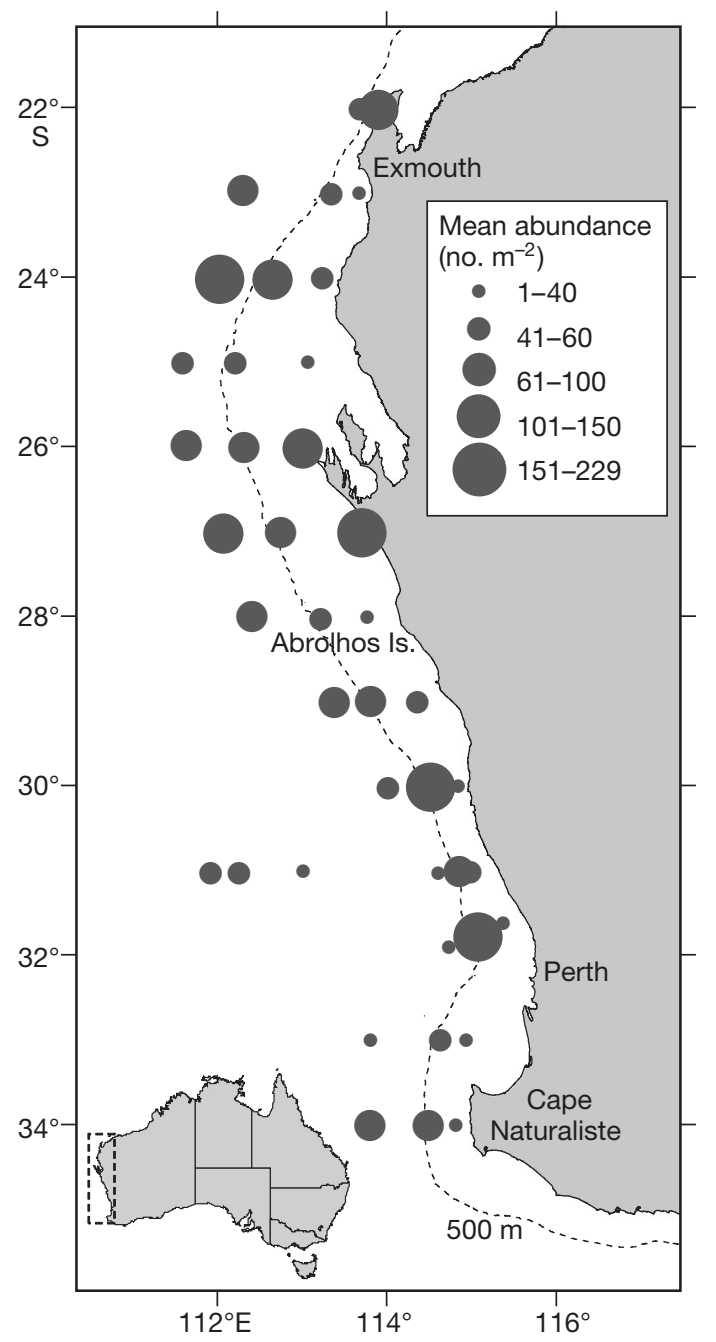

Fig. 1. Mean abundance (no. $\mathrm{m}^{-2}$ ) of larval fishes at stations $(50,300$ and $2000 \mathrm{~m}$ isobaths) along 13 transects off the coast of Western Australia during the study in late austral autumn, May 2007 centre and shoreward (east) perimeter. Stations within the eddy were located using available satellite imagery as well as in situ underway measurement of the horizontal current velocity field.

Sampling of larval fishes was concurrent with the in situ measurement of the oceanography; specifically, water column profiling (conductivity-temperature-depth-oxygen, CTD- $\mathrm{O}_{2}$ ) and horizontal velocity field (acoustic doppler current profiler) measurements (Thompson et al. 2011, Weller et al. 2011). CTD- $\mathrm{O}_{2}$ profiles were obtained using a Seabird SBE $19+$ instrument, which was equipped with dual temperature and conductivity sensors, an oxygen sensor and a Chelsea TGI fluorometer. These data were used to determine mixed layer depth and to characterise water masses. The mixed layer depth was determined where a change in potential density of

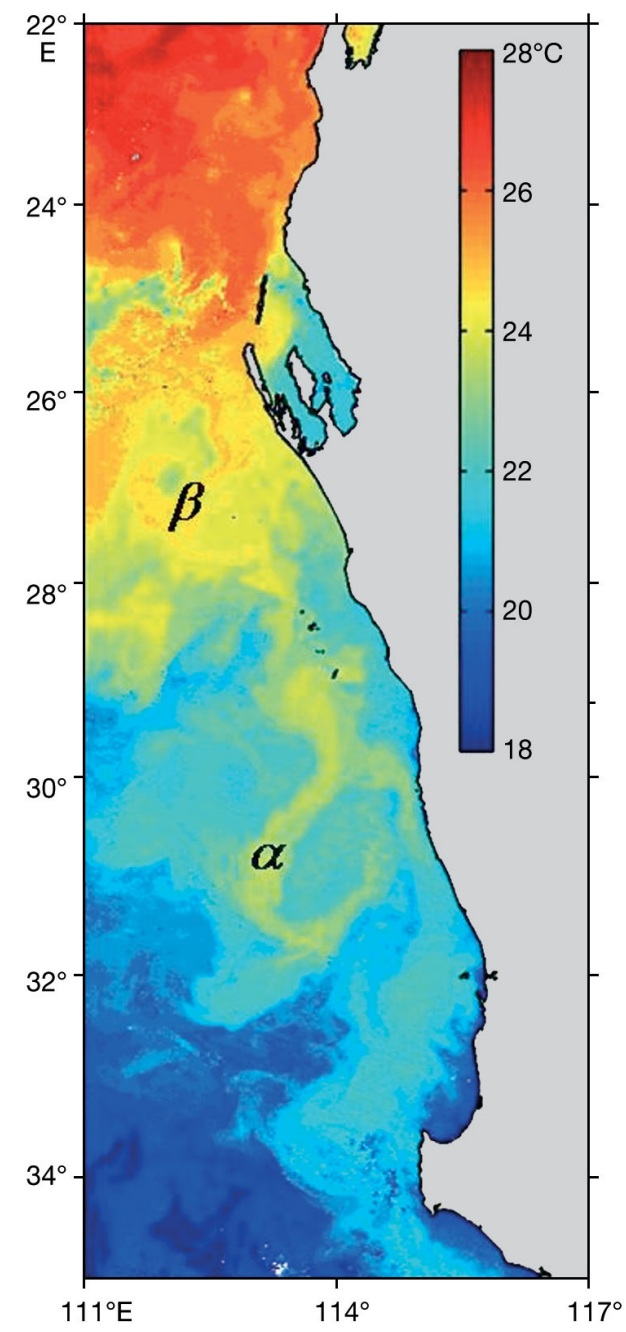

Fig. 2. Single-day sea-surface temperature from GHRSST $\left(\sim 1 \mathrm{~km}\right.$ resolution) showing the anticyclonic eddies at $\sim 31^{\circ} \mathrm{S}$ and $27^{\circ} \mathrm{S}$ ( $\alpha$ and $\beta$, respectively) off Western Australia on 9 May 2007. Figure is modified from Weller et al. (2011) 
the water column of $0.125 \mathrm{~kg} \mathrm{~m}^{-3}$ defined the bottom of the mixed layer (Levitus 1982, Feng et al. 2007).

Larval fishes were collected using a paired bongo net $\left(100\right.$ and $355 \mu \mathrm{m}$ meshes, mouth area $0.196 \mathrm{~m}^{2}$, diameter $0.6 \mathrm{~m}$ ), but only samples from the $355 \mu \mathrm{m}$ net were used for this study (the $100 \mu \mathrm{m}$ samples were for a separate zooplankton study). Sampling of larval fishes was made from a maximum depth of $150 \mathrm{~m}$, or shallower, to the surface and nets were towed obliquely for $15 \mathrm{~min}$ with the ship steaming at approximately 2 knots. Because of logistical and time constraints of a lengthy voyage, the survey resulted in sampling stations being occupied during both day and night but sampling was timed to avoid diel migration of zooplankton, i.e. $1 \mathrm{~h}$ before and after sunrise and sunset.

The volume of water sampled by each net was measured using a mechanical General Oceanics flowmeter positioned centrally in the mouths of each of the 100 and $355 \mu \mathrm{m}$ nets. All flowmeters were linked to an electronic interface from which the volume of water through the nets and the tow profile could be monitored. Upon retrieval, $355 \mu$ m samples were preserved in $5 \%$ buffered formalin solution. Using a dissecting microscope, larval fishes were extracted from all $355 \mu \mathrm{m}$ plankton samples and identified using relevant literature (e.g. Moser \& Ahlstrom 1970, Moser et al. 1984, Olivar et al. 1999, Neira et al. 1998, Olivar \& Fortuño 1991, Leis \& Carson-Ewart 2000, Moser \& Watson 2005, Richards 2006). In many instances, larval fishes could only be identified to the family level due to early stages of development and lack of adequate descriptions. For larvae not identified to species, types were assigned based on different morphological and pigmentation characteristics (sensu Leis \& Carson-Ewart 2000).

\section{Data analyses}

The concentrations of larval fishes were standardised to number of larvae per square metre by multiplying by the maximum depth of each plankton tow. Although some earlier studies from the region (e.g. Muhling \& Beckley 2007, Muhling et al. 2008) used concentration, in this study, abundance was used to enable global comparisons and also because this is the recommended procedure (Smith \& Richardson 1977). Abundances of larval fishes were square-root transformed and examined to ascertain whether there were any significant differences between the a priori factors of Latitude and Isobath $(50,300$ and $2000 \mathrm{~m}$ isobaths) using a 2-way crossed ANOVA design in SPSS 14.0 that also tested the interaction term of Latitude $\times$ Isobath.

Because vertical distribution of marine fish larvae is usually restricted to the upper $150-200 \mathrm{~m}$ of the water column (John et al. 2001, Hare \& Govoni 2005, Muhling \& Beckley 2007), day and night differences in concentrations owing to vertical migration were not expected. Data for this study indicated that larval fishes were similarly abundant in day and night samples in shelf and offshore waters in the study region. Day and night samples were therefore treated the same for the purpose of statistical analysis, but it is acknowledged that some of the variability in the data set may be due to diel variation.

Larval fish assemblage structure was examined using the Primer-6 software package (Clarke \& Warwick 2005). Prior to analysis, larval fish abundances were $\log (\mathrm{x}+1)$-transformed to reduce the weighting of dominant taxa and a Bray-Curtis resemblance matrix was constructed. The assemblage matrix was constructed for larvae that were identified to the best possible taxonomic level, although often this was only to family level.

A 2-factor permutational MANOVA (PERMANOVA+ for Primer-6; Anderson 2005) was used to test the hypothesis that larval fish assemblages did not differ in the latitudinal and cross-shelf directions, i.e. between the a priori factors Latitude and Isobath. The PERMANOVA routine also tested for an interaction between the 2 factors (Latitude $\times$ Isobath). In the event of a significant interaction term, insufficient replication of the factor Isobath at each level of latitude prevented subsequent pairwise comparisons (post hoc testing) to further examine structuring of the larval fish assemblages in relation to these factors. Effects of diel variability could not be tested as there was insufficient replication of this factor at the levels of latitude and isobath because of the geographical extent of the research voyage.

Although the data set was structured based upon the pre-defined factors of Latitude and Isobath, the exploratory techniques of hierarchical group-averaged clustering and the similarity profile (SIMPROF) test were applied to better elucidate any structuring of the larval fish assemblages. Clustering and SIMPROF analyses were run simultaneously to test the hypothesis that larval fish assemblages did not differ from each other; that is, there was no significant group structuring of larval fish assemblages. The SIMPROF routine tests the significance of any structuring in the data that is not distinguished into a priori groups. The relationship (similarity) between the cluster groups (larval fish assemblages) was eval- 
uated using non-metric multi-dimensional scaling (nMDS) ordination. The similarity percentage (SIMPER) routine was then applied to identify the taxa most responsible for similarities or differences between the larval fish assemblages.

Larval fish assemblages were correlated with a suite of environmental variables (temperature, salinity, dissolved oxygen, chlorophyll a concentration and distance from shore) using the BVSTEP sub-routine. This analysis determined which subset from the full suite of environmental variables provided the best match with the larval fish assemblages and determined whether the match was statistically significant $(p<0.05)$. Each environmental variable, excluding distance from shore, was expressed as a mean of the mixed layer for each sampling station. Prior to analysis, the choice of appropriate transformation of each variable was determined by graphing the variables in pairwise scatter plots. The variables of salinity and dissolved oxygen were subsequently omitted from the analysis as they had a linear relationship with temperature (positively and negatively, respectively); the inclusion of temperature served as a surrogate for these 2 variables. Data were normalised and a resemblance matrix was constructed based on Euclidean distance.

\section{Lagrangian particle tracking}

The 3-dimensional Lagrangian particle tracking used in this study was based on the hydrodynamic model output of Bluelink ReAnalysis (BRAN). BRAN is forced by the European Centre for Medium-Range Weather Forecasts (ECMWF) wind stress, and heat and freshwater flux-forcing at the sea surface, and is 'corrected' by assimilated satellite and in situ oceanography observations (Oke et al. 2008). Weller et al. (2011) demonstrated that BRAN produced a good representation of oceanographic conditions during the study and was in agreement with empirical oceanographic measurements.

As BRAN may not reproduce the exact location of an eddy for a given date because of the differences between the free-running physics in the model, the forcing data and the relaxation data, the output from $1 \mathrm{wk}$ prior to and $1 \mathrm{wk}$ after the sampling dates were examined for the closest spatial match to the observed eddy cores. This match was then used as the reference model date for particle seeding and tracking. Reference dates for the $27^{\circ} \mathrm{S}$ and $31^{\circ} \mathrm{S}$ eddies were 28 and 24 May 2007, respectively.
For the developing eddy at $27^{\circ} \mathrm{S}, 7000$ particles were randomly seeded at $1 \mathrm{~m}$ depth and every $10 \mathrm{~m}$ depth between 5 and $500 \mathrm{~m}$ for a total of 357000 particles. The spatial seeding was done in a square with dimensions of $0.75^{\circ}$ by $0.75^{\circ}$ that was centred over the eddy. This was then sub-sampled for analysis using a circle with a radius of $0.25^{\circ}$ centred over the eddy between 0 and $200 \mathrm{~m}$ depth. This resulted in 12138 particles that were used for particle tracking analysis. Seeding of the eddy located at $31^{\circ} \mathrm{S}$ used a circle with a radius of $1.25^{\circ}$ and 1000 particles were released in each depth stratum, giving a total of 51000 particles. This was then sub-sampled for particles seeded between 0 and $200 \mathrm{~m}$, resulting in 21000 particles used for analysis.

To track the source water mass, particles were backtracked for 4 wk using the daily velocity field from BRAN. A 4th-order Runga-Kutta sub-time-stepping scheme was used to update the particle locations every $6 \mathrm{~h}$ (by linearly interpolating velocity from daily fields). Random walk (dispersion) was not applied in updating particle locations during the particle tracking; however, we randomly perturbed the initial seeding locations within the release area to simulate some random effects.

\section{RESULTS}

This study sampled 13944 larval fishes from 114 families comprising tropical and temperate as well as oceanic and neritic taxa (see the Supplement at www.int-res.com/articles/suppl/m460p127_supp.xls). The majority of larval fishes captured were small preand early flexion stages ( $<5.0 \mathrm{~mm}$ standard length, $\mathrm{SL}$ ). In general, the mean abundance of larval fishes along the Western Australia coastline was highest at the shelf break $(300 \mathrm{~m})$ (mean: 97 larvae $\mathrm{m}^{-2}$, range: 34-240 larvae $\mathrm{m}^{-2}$ ) compared with over the inner shelf $(50 \mathrm{~m})$ (mean: 64 larvae $\mathrm{m}^{-2}$, range: $7.5-195$ larvae $\mathrm{m}^{-2}$ ) and in oceanic waters (2000 m) (mean: 70 larvae $\mathrm{m}^{-2}$, range: $10-138$ larvae $\mathrm{m}^{-2}$; Figs. 1 \& 3). High abundances at oceanic stations were generally in association with mesoscale features; for example, the very high abundance (mean: 175 larvae $\mathrm{m}^{-2}$ ) at an oceanic station at $24^{\circ} \mathrm{S}$ was in association with a cyclonic feature (see Weller et al. 2011). A developing anticyclonic eddy at $27^{\circ} \mathrm{S}$ (see Fig. 2) had a mean abundance of 146 larvae $\mathrm{m}^{-2}$ but, comparatively, the abundance of larval fishes in an older anticyclonic eddy at $\sim 31^{\circ} \mathrm{S}$ was lower (mean: 34.7 larvae $^{-2}$ ).

Overall, there were significant differences in the abundances of larval fishes among latitudes and 


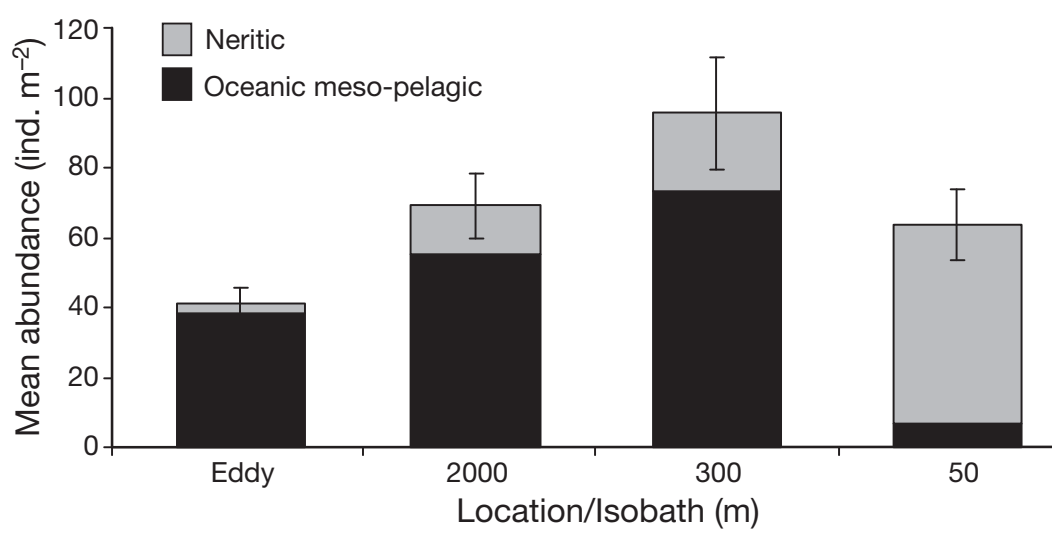

Fig. 3. Mean abundance of larval fishes in inner shelf $(50 \mathrm{~m})$, shelf break $(300 \mathrm{~m})$, oceanic $(2000 \mathrm{~m})$ and eddy waters off the coast of Western Australia in the late austral autumn, May 2007. Abundances were averaged across latitudes from $22^{\circ} \mathrm{S}$ to $34^{\circ} \mathrm{S}$ and standard errors are shown
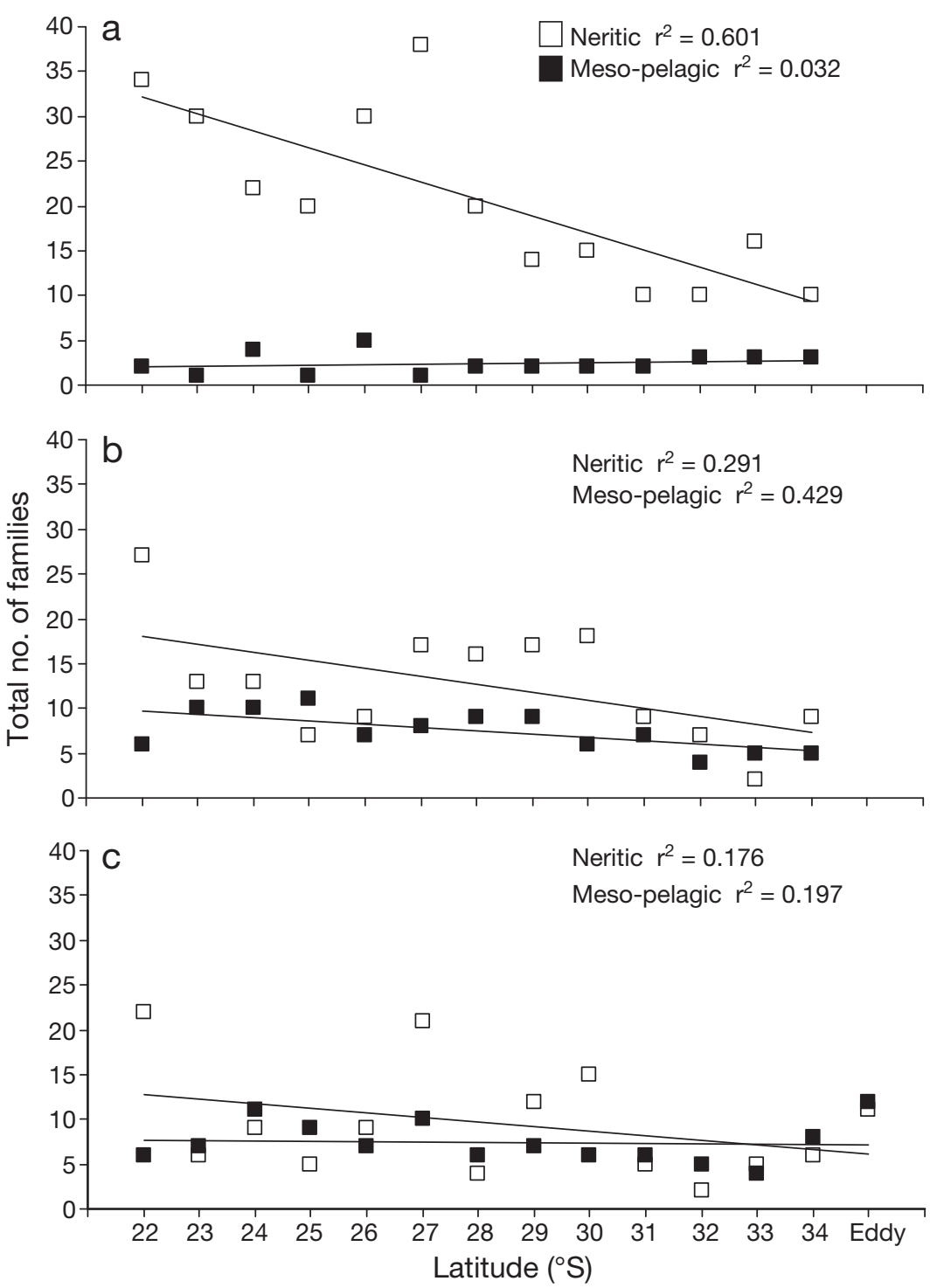

isobaths, with a significant interaction between the 2 factors $(\mathrm{p}<0.001$; Table 1). Most of the variability was explained by isobath, as indicated by the higher mean square estimate. One-way ANOVA confirmed that the mean abundance of larval fishes was significantly higher $(p=0.035)$ at the shelf break compared with the inner shelf (Fig. 3). There was no significant difference between shelf break and oceanic stations $(p=0.5)$ or between inner shelf and oceanic stations $(p>$ $0.3)$. We acknowledge the possibility of diel effects that might have contributed to the observed variability in abundance and composition of larval fish; standardization of the bongo tows to $150 \mathrm{~m}$ depth (deeper than the photic zone, or to within a few metres of the bottom in shallower water) effectively sampled most of the water column where larval fish reside and therefore should have minimised any diel effects.

Regression analysis showed that, in general, there was a reduction in the total number of neritic and oceanic meso-pelagic families from lower to higher latitudes (Fig. 4). This trend was strongest over the inner shelf for neritic families $\left(r^{2}=0.601\right.$; Fig. 4a). Diversity was higher (mean: 29 families) north of $28^{\circ} \mathrm{S}$ compared with south of this latitude (mean: 11 families), and this was due to the greater number of tropical reef-associated taxa present at lower latitudes. For oceanic meso-pelagic families, the strongest latitudinal trend was along

Fig. 4. Regression analysis comparing the contribution of larvae of neritic and oceanic meso-pelagic fish taxa to overall diversity at the family level for assemblages sampled at stations representing (a) $50 \mathrm{~m}$ (inner shelf), (b) $300 \mathrm{~m}$ (shelf break) and (c) $2000 \mathrm{~m}$ (oceanic) isobaths along a latitudinal gradient from $22^{\circ} \mathrm{S}$ to $34^{\circ} \mathrm{S}$ off the coast of Western Australia in late austral autumn, May 2007. Results are also given for the assemblage that characterised an anticyclonic eddy located offshore at $\sim 31^{\circ} \mathrm{S}$ 
Table 1. Results of 2-way ANOVA testing for differences in mean abundance (no. $\mathrm{m}^{-2}$ ) of larval fishes for the factors Latitude and Isobath, i.e. $50 \mathrm{~m}$ (inner shelf), $300 \mathrm{~m}$ (shelf break) and $2000 \mathrm{~m}$ (oceanic), for samples collected off the coast of Western Australia between $22^{\circ} \mathrm{S}$ and $34^{\circ} \mathrm{S}$ in late austral autumn, May 2007

\begin{tabular}{|lrrrc|}
\hline Factor & df & MS & \multicolumn{1}{c|}{$F$} & $\mathrm{p}$ \\
\hline Latitude & 12 & 15.2 & 7.8 & $<0.001$ \\
Isobath & 2 & 32.4 & 16.7 & $<0.001$ \\
Latitude $\times$ Isobath & 24 & 18.3 & 9.4 & $<0.001$ \\
Residual & 39 & 1.9 & & \\
Total & 78 & & & \\
\hline
\end{tabular}

the shelf break $\left(r^{2}=0.429 ;\right.$ Fig. $\left.4 b\right)$. Oceanic stations at $22^{\circ} \mathrm{S}$ and $27^{\circ} \mathrm{S}$ (the latter in association with a developing anticyclonic eddy) were characterised by relatively high numbers of neritic families $(\mathrm{n}=22$ and 21 families, respectively). In contrast, the older eddy situated offshore at $31^{\circ} \mathrm{S}$ had fewer neritic families ( $\mathrm{n}=12$ families). Corresponding with the offshore occurrence of neritic larvae, the larvae of oceanic meso-pelagic fishes were distributed over the inner shelf along the entire surveyed coastline. As could be expected, the diversity of meso-pelagic fishes was lowest over the inner shelf compared with oceanic waters, and there was no difference in diversity between low and high latitudes (Fig. 4c).

Five families contributed $>70 \%$ of the total catch: Myctophidae (33\%), Phosichthyidae (15\%), Engraulidae $(15 \%)$, Clupeidae $(8 \%)$ and Bregmacerotidae $(6 \%)$. Diversity at the family level was greatest for neritic taxa $(n=100)$ and comprised families that were both pelagic and demersal as adults, including coastal and reef-associated taxa (e.g. Apogonidae, Gobiidae, Labridae, Pomacentridae, Serranidae; see Supplement).

The percentage composition by family of larval fishes for assemblages representing inner shelf, shelf break and oceanic isobaths given in Table 2 describes the general cross-shelf trend in diversity off the Western Australian coast during this study. Overall, neritic taxa accounted for $89 \%$ of the total inner shelf assemblage and were dominated by larvae of the Engraulidae (mainly Engraulis australis; 37\%) and Clupeidae (mainly Sardinops sagax and Etrumeus teres; $>11 \%$ ). Collectively, larvae of oceanic meso-pelagic families, in particular the ubiquitously distributed Myctophidae and Phosichthyidae, contributed $>13 \%$ to the inner shelf assemblage.

Assemblages at the shelf break were dominated by larvae of the Myctophidae (particularly Diaphus spp. slender morphotype; $>48 \%$ ) and Phosichthyidae
Table 2. Percent composition of larval fish assemblages, showing the 10 most abundant families by mean abundance (larvae $\mathrm{m}^{-2}$ ) for each isobath, i.e. $50 \mathrm{~m}$ (inner shelf), $300 \mathrm{~m}$ (shelf break) and $2000 \mathrm{~m}$ (oceanic), which are averaged across latitudes. Oceanic families are indicated by the superscript ' $o$ '. Asterisks denote the presence of taxa in each assemblage but in low abundances. Results are shown for all samples collected off the coast of Western Australia between $22^{\circ} \mathrm{S}$ and $34^{\circ} \mathrm{S}$ in late austral autumn, May 2007

\begin{tabular}{|c|c|c|c|c|}
\hline Family & $\begin{array}{l}\text { Inner } \\
\text { shelf }\end{array}$ & $\begin{array}{l}\text { Shelf } \\
\text { break }\end{array}$ & Oceanic & Eddy \\
\hline Apogonidae & 4.3 & * & & \\
\hline Bregmacerotidae & 7.2 & 4.4 & 3.4 & 4.9 \\
\hline Callionymidae & 1.5 & * & $*$ & \\
\hline Champsodontidae & 2.8 & * & * & $*$ \\
\hline Chauliodontidae $^{\circ}$ & & * & * & 1.4 \\
\hline Clupeidae & 11.7 & 3.1 & $*$ & \\
\hline Engraulidae & 37.0 & 1.4 & 7.0 & \\
\hline Gobiidae & 2.8 & $*$ & $*$ & \\
\hline Gonostomatidae $^{\circ}$ & $*$ & 2.0 & 2.8 & 0.5 \\
\hline Labridae & 1.2 & 1.7 & $*$ & 0.4 \\
\hline Myctophidae $^{\circ}$ & 7.2 & 48.7 & 45.8 & 38.5 \\
\hline Notosudidae $^{o}$ & $*$ & 2.1 & 2.0 & 7.1 \\
\hline Paralepididae $^{\circ}$ & * & * & 1.1 & $*$ \\
\hline Phosichthyidae $^{\circ}$ & 3.2 & 18.5 & 20.5 & 36.0 \\
\hline Pomacentridae & * & 1.1 & & \\
\hline Scombridae & * & 1.5 & $*$ & \\
\hline Scopelarchidae $^{o}$ & & $*$ & 1.8 & 1.2 \\
\hline Serranidae & * & & $*$ & 0.2 \\
\hline Sternoptychidae $^{\circ}$ & & * & 2.7 & 0.8 \\
\hline Triglidae & * & & 1.4 & \\
\hline Other neritic taxa & 20.2 & 10.0 & 8.2 & 1.8 \\
\hline Other meso-pelagic taxa & 0.6 & 3.6 & 1.6 & 2.0 \\
\hline
\end{tabular}

(mostly Vinciguerria spp.; >18\%; Table 2). Overall, the larvae of oceanic meso-pelagic taxa accounted for $75 \%$ of the total shelf break assemblage but the number of families was generally lower towards the south of the study area (Fig. 4b). The larvae of neritic families comprised $23 \%$ of the total shelf break assemblage, the most abundant of which were Bregmacerotidae $(4 \%)$ and Clupeidae $(3 \%$; Table 2$)$. The diversity of neritic taxa at the shelf break decreased southwards $\left(27\right.$ families at $22^{\circ} \mathrm{S}$ and 9 families at $34^{\circ} \mathrm{S}$; Fig. $4 \mathrm{~b}$ ) and there was a greater diversity of tropical reef-associated taxa at lower latitudes.

Assemblages in oceanic waters were dominated by Myctophidae (46\%) and Phosichthyidae (20\%) larvae (Table 2). The larvae of neritic fishes were distributed offshore and the most abundant of these was Engraulis australis, which accounted for $7 \%$ of the total oceanic assemblage, although the distribution of these larvae was spatially restricted and they only occurred in high numbers at $27^{\circ} \mathrm{S}$. The larvae of coastal and reef-associated taxa were also recorded offshore at $27^{\circ} \mathrm{S}$ and included the acanthurid Naso 
sp., ptereleotrine microdesmids (Ptereleotris sp.), an epinepheline serranid and a chaetodontid. Similarly, larvae of neritic fishes were also captured in the $31^{\circ} \mathrm{S}$ anticyclonic eddy and included bregmacerotid larvae, serranid larvae, some labrids and a single ptereleotrine microdesmid (Ptereleotris sp.).

Regression analyses revealed that, over the inner shelf, abundances of neritic larvae decreased towards higher latitudes $\left(\mathrm{r}^{2}=0.302\right)$ whereas the abundance of meso-pelagic larvae increased off the south-
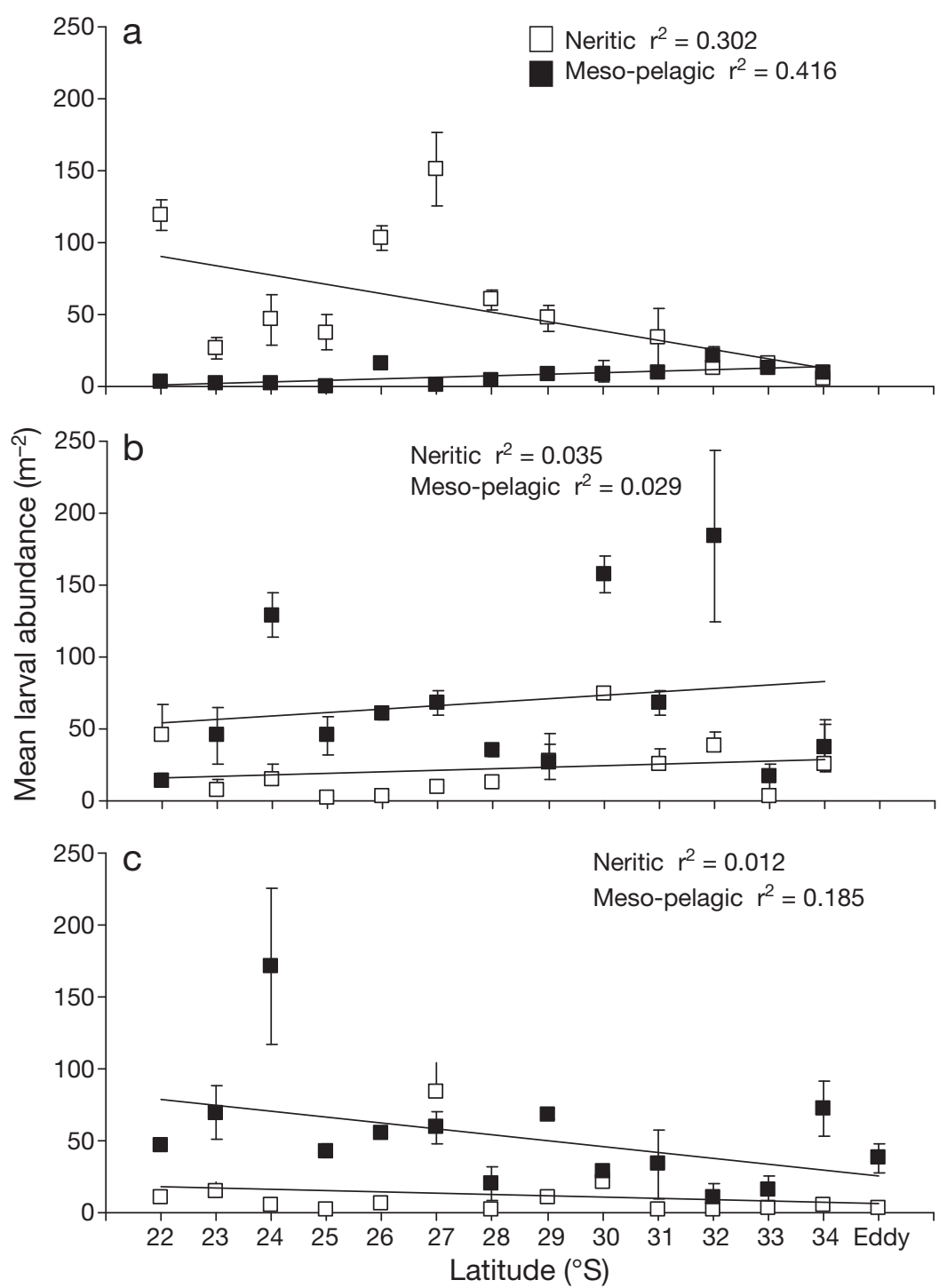

Fig. 5. Regression analysis comparing the mean abundance (no. $\mathrm{m}^{-2}$ ) of larvae of neritic and oceanic meso-pelagic fishes at stations representing (a) $50 \mathrm{~m}$ (inner shelf), (b) $300 \mathrm{~m}$ (shelf break) and (c) $2000 \mathrm{~m}$ (oceanic) isobaths along a latitudinal gradient from $22^{\circ} \mathrm{S}$ to $34^{\circ} \mathrm{S}$ off the coast of Western Australia in late austral autumn, May 2007. Results are also given for the assemblage that characterised an anticyclonic eddy located offshore at $\sim 31^{\circ} \mathrm{S}$. Those samples where the error bars are not discernable were characterised with variances of $<5$ larvae $\mathrm{m}^{-2}$ western Australian coast (mean: $<2$ to 11 larvae $\mathrm{m}^{-2}$; $\mathrm{r}^{2}=0.416$; Fig. 5a). The highest abundance (mean of 20 larvae $\mathrm{m}^{-2}$ ) of meso-pelagic larvae over the inner shelf was recorded at $32^{\circ} \mathrm{S}$. There were no latitudinal trends in the abundances of neritic and oceanic meso-pelagic taxa along the shelf break and in oceanic waters (Fig. 5b,c). Abundances of neritic larvae were generally lowest in oceanic waters $(<10$ larvae $\mathrm{m}^{-2}$ ). The exception was a high abundance of larvae (mostly Engraulis australis; mean: 84 larvae $\mathrm{m}^{-2}$ ) recorded at the oceanic station at $27^{\circ} \mathrm{S}$ in association with a developing anticyclonic eddy and contrasted with the substantially lower abundance of neritic taxa (mean: 3 larvae $\mathrm{m}^{-2}$ ) recorded in the older eddy at $\sim 31^{\circ} \mathrm{S}$. There were fewer neritic larvae distributed over the shelf break from $23^{\circ} \mathrm{S}$ to $28^{\circ} \mathrm{S}$ compared with further south, whereas abundances of meso-pelagic larvae displayed a high amount of variability.

Two larval fish taxa were used as biological tracers of cross-shelf transport: the epipelagic engraulid Engraulis australis and the meso-pelagic myctophid Diaphus spp. (slender morphotype). Larval E. australis were found in highest abundances over the inner shelf between $22^{\circ} \mathrm{S}$ and $28^{\circ} \mathrm{S}$, decreasing towards higher latitudes where few or complete absence of these larvae was recorded (Fig. 6a). Besides the very high abundance in oceanic waters at $27^{\circ} \mathrm{S}$, the larvae of E. australis were generally restricted to the inner shelf at lower latitudes. Length frequencies of E. australis larvae showed a higher contribution of early stages $(<4 \mathrm{~mm} \mathrm{SL})$ at the inner shelf, with the notable absence of larvae larger $>6 \mathrm{~mm} \mathrm{SL}$ at $25^{\circ} \mathrm{S}$ and $27^{\circ} \mathrm{S}$. However, this small cohort, as well as some larger specimens up to $15 \mathrm{~mm} \mathrm{SL}$ (Fig. 7), was recorded at the oceanic station at $27^{\circ} \mathrm{S}$. Comparing the size structure of $E$. australis larvae between the inner shelf and oceanic stations at $27^{\circ} \mathrm{S}$, a Kolmogrov-Smirnov test found that there was no significant difference in mean larval lengths ( $p=0.33$ ). This is considered to be indicative of connection of the water at this oceanic station with the shelf during the previous weeks. 

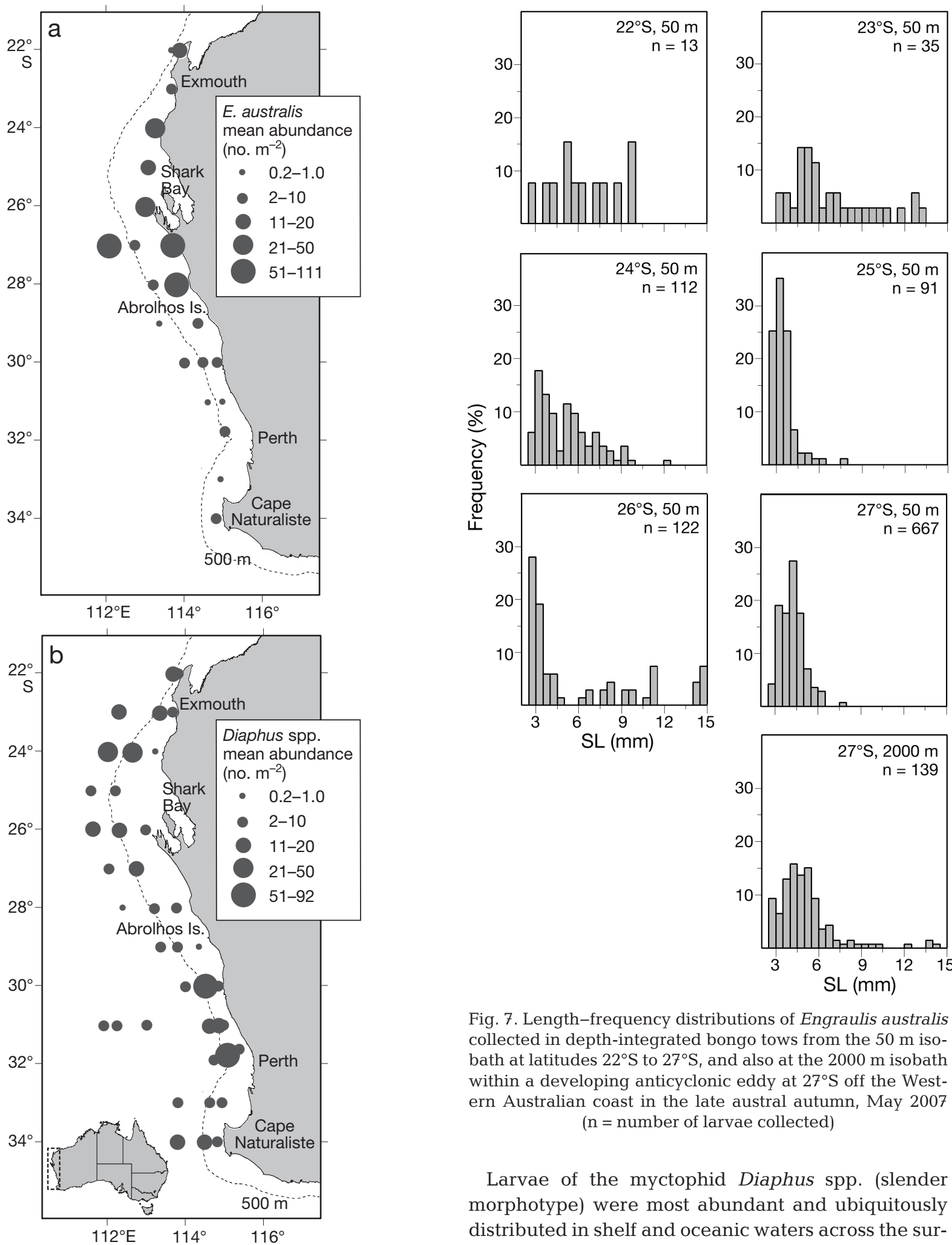

Fig. 6. Mean abundance (no. $\mathrm{m}^{-2}$ ) of (a) Engraulis australis and (b) Diaphus spp. (slender morphotype) larvae at stations $(50,300$ and $2000 \mathrm{~m}$ isobaths) along 13 transects off the coast of Western Australia in late austral autumn, May 2007

Larvae of the myctophid Diaphus spp. (slender morphotype) were most abundant and ubiquitously distributed in shelf and oceanic waters across the surveyed area, although the highest abundances were recorded at the shelf break (Fig. 6b). Over the inner shelf, abundances of Diaphus spp. larvae were highest at latitudes south of $28^{\circ} \mathrm{S}$.

Fig. 7. Length-frequency distributions of Engraulis australis collected in depth-integrated bongo tows from the $50 \mathrm{~m}$ isobath at latitudes $22^{\circ} \mathrm{S}$ to $27^{\circ} \mathrm{S}$, and also at the $2000 \mathrm{~m}$ isobath within a developing anticyclonic eddy at $27^{\circ} \mathrm{S}$ off the Western Australian coast in the late austral autumn, May 2007 ( $\mathrm{n}=$ number of larvae collected) 


\section{Assemblages}

Two-factor PERMANOVA revealed similarly significant structuring of larval fish assemblages with both latitude and isobath, as indicated from the components of variation (Table 3 ), and there was a significant interaction term between these 2 factors.

Multidimensional scaling ordination of larval fish assemblages showed clear spatial separation of the inner shelf stations from $22^{\circ} \mathrm{S}$ to $28^{\circ} \mathrm{S}$. Inner shelf stations from $29^{\circ} \mathrm{S}$ to $34^{\circ} \mathrm{S}$ were delineated as a distinct assemblage and were not separated as strongly in the nMDS ordination (Fig. 8). In general, assemblages at the shelf break and oceanic stations grouped together with a clear latitudinal gradient evident.

Seven statistically significant larval fish assemblages (and 3 outliers) were identified from hierarchical cluster and SIMPROF analyses. The major delineation was between a northern inner shelf assemblage (A) that included the shelf break station at $22^{\circ} \mathrm{S}$ and another assemblage (D) that incorporated stations within the eddy field between $29^{\circ} \mathrm{S}$ and $34^{\circ} \mathrm{S}$ as well as shelf break stations from $26^{\circ} \mathrm{S}$ to $28^{\circ} \mathrm{S}$ (Fig. 9). The other statistically significant assemblages each represented a small number of sampling locations differentiated by high concentrations of the clupeid Sardinops sagax or variable abundances of the ubiquitous myctophid species (Table 4). The assemblage at the oceanic station at $27^{\circ} \mathrm{S}$ was significantly different from other offshore stations because of the very high abundance of larval engraulids. Delineation between the northern inshore assemblages and all other larval fish assem-
Table 3. Two-factor PERMANOVA testing the effect of Latitude, Isobath and their interaction on the structuring of larval fish assemblages off the coast of Western Australia in late austral autumn, May 2007

\begin{tabular}{|lccccc|}
\hline Factor & df & MS & CV & $\begin{array}{c}\text { Pseudo- } \\
F\end{array}$ & $p$ \\
& & & & & \\
\hline Latitude & 12 & 5361 & 27.1 & 5.7 & $<0.001$ \\
Isobath & 2 & 17943 & 25.6 & 19.1 & $<0.001$ \\
Latitude $\times$ Isobath & 24 & 3098 & 32.9 & 3.3 & $<0.001$ \\
$\begin{array}{l}\text { Residual } \\
\text { Total }\end{array}$ & 39 & 939 & 30.6 & & \\
\hline
\end{tabular}

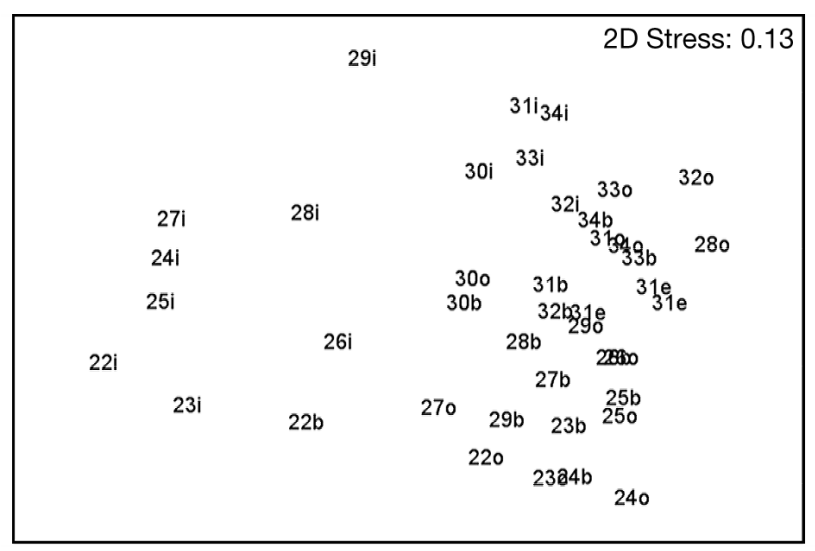

Fig. 8. Multi-dimensional scaling representation of larval fish assemblage structure for all stations sampled over the shelf and offshore along the Western Australian coastline from $22^{\circ} \mathrm{S}$ to $34^{\circ} \mathrm{S}$ in late austral autumn, May 2007. Samples are coded by latitude (numeric) followed by location: inner shelf (i), shelf break (b), oceanic (o) or eddy (e)

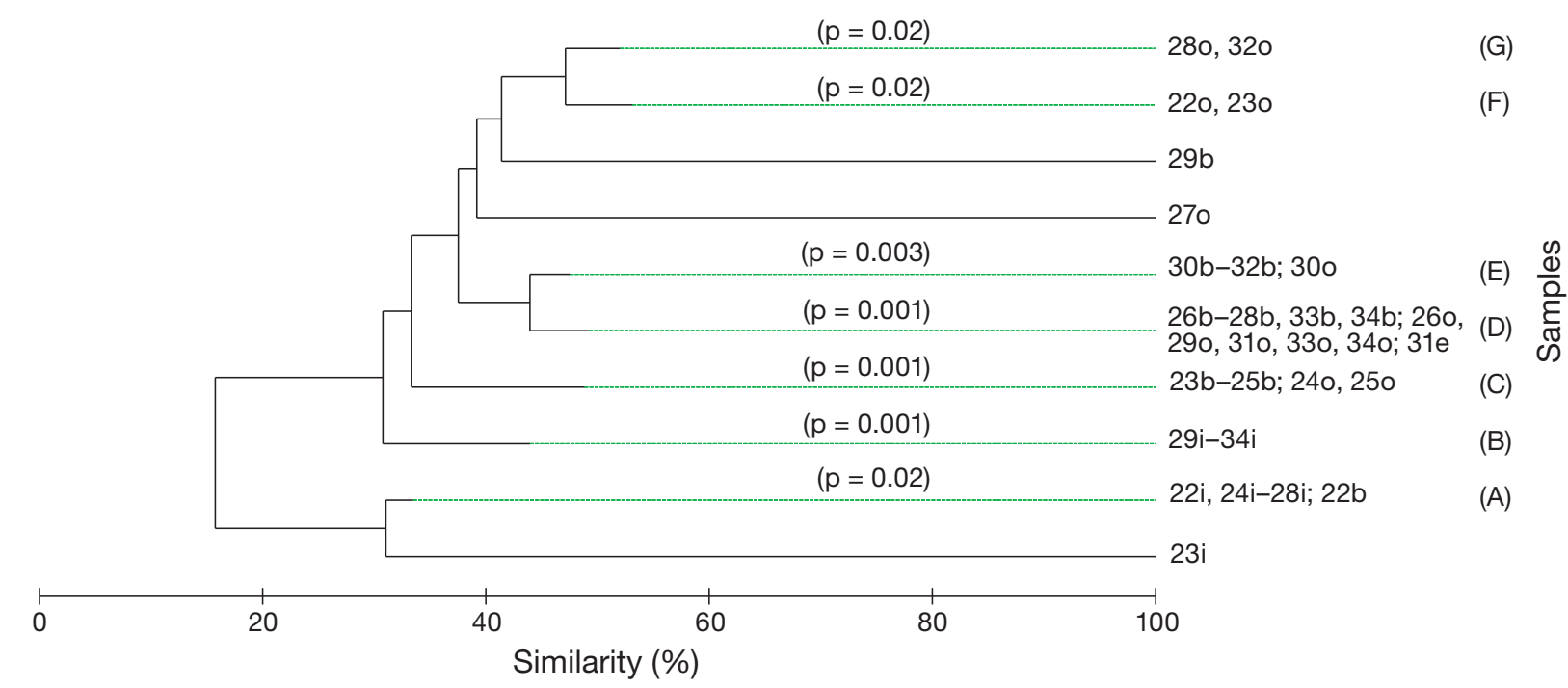

Fig. 9. Dendrogram generated from a Bray-Curtis similarity matrix of larval fish assemblages from 42 stations representing $50 \mathrm{~m}$ (inner shelf, i), $300 \mathrm{~m}$ (shelf break, b) and $2000 \mathrm{~m}$ (oceanic, o) isobaths that were sampled off the coast of Western Australia in late austral autumn, May 2007. The assemblages identified by SIMPROF (A-G) are shown along with their respective statistical significance levels. Samples coded as in Fig. 8 
Table 4. One-way ANOSIM and SIMPER analyses between larval fish assemblages (A to F) classified from similarity profile testing (see Fig. 9). The species listed are those that contributed the most and the most consistently to the differences between assemblages. Superscript letter refers to the assemblage in which the given family was more abundant. Percentages shown are the average dissimilarity between assemblages

\begin{tabular}{|c|c|c|c|c|c|c|}
\hline A & $\begin{array}{l}60 \% \\
\text { Engraulis australis } \\
\text { Bregmaceros spp. } \\
\text { Type I }\end{array}$ & & & & & \\
\hline B & $\begin{array}{l}82 \% \\
\text { E. australis } \\
\text { S. } \text { sagax }^{\mathrm{B}} \\
\text { Bregmaceros spp. } \\
\text { Type I }^{\mathrm{A}}\end{array}$ & $\begin{array}{l}47 \% \\
\text { Sardinops sagax } \\
\text { Diaphus spp. } \\
\text { (slender) } \\
\text { Vinciguerria spp. } \\
\text { Labridae spp. } \\
\text { Lampanyctus } \\
\text { alatus }\end{array}$ & & & & \\
\hline C & $\begin{array}{l}87 \% \\
\text { E. australis }\end{array}$ & $\begin{array}{l}78 \% \\
\text { S. } \text { sagax }^{\mathrm{B}} \\
\text { Hygophum } \\
\text { proximum }^{\mathrm{C}}\end{array}$ & $\begin{array}{l}45 \% \\
\text { Diaphus spp. } \\
\text { (slender) } \\
\text { Vinciguerria spp. } \\
\text { Diaphus spp. } \\
\text { (deep) } \\
\text { L. alatus } \\
\text { V. nimbaria }\end{array}$ & & & \\
\hline $\mathrm{D}$ & $\begin{array}{l}86 \% \\
\text { E. australis }\end{array}$ & $\begin{array}{l}65 \% \\
\text { S. } \text { sagax }^{\mathrm{B}} \\
\text { Vinciguerria spp. }^{\mathrm{D}} \\
\text { V. nimbaria } \\
\text { Notosudidae spp. }\end{array}$ & $\begin{array}{l}59 \% \\
\text { H. proximum }\end{array}$ & $\begin{array}{l}49 \% \\
\text { Diaphus spp. } \\
\text { (slender) } \\
\text { Vinciguerria spp. } \\
\text { V. nimbaria } \\
\text { L. alatus } \\
\text { Notosudidae spp. } \\
\text { Hygophum hygomii }\end{array}$ & & \\
\hline E & $\begin{array}{l}77 \% \\
\text { Diaphus spp. } \\
\text { (slender) }^{\mathrm{E}} \\
\text { Vinciguerria spp. }^{\mathrm{E}} \\
\text { E. australis }\end{array}$ & $\begin{array}{l}63 \% \\
\text { Diaphus spp. } \\
\text { (slender) }^{\mathrm{E}} \\
\text { Vinciguerria spp. }^{\mathrm{E}} \\
\text { Bregmaceros spp. } \\
\text { Type II }{ }^{\mathrm{E}} \\
\text { Diaphus spp. } \\
\text { (deep) }^{\mathrm{E}}\end{array}$ & $\begin{array}{l}63 \% \\
\text { Low and } \\
\text { inconsistent } \\
\text { contributions } \\
\text { of several taxa }\end{array}$ & $\begin{array}{l}56 \% \\
\text { S. } \operatorname{sagax}^{\mathrm{E}}\end{array}$ & $\begin{array}{l}48 \% \\
\text { Diaphus spp. } \\
\text { (slender) } \\
\text { Vinciguerria spp. } \\
\text { Diaphus spp. } \\
\text { (deep) } \\
\text { S. sagax } \\
\text { Bregmaceros spp. } \\
\text { Type II } \\
\text { Vinciguerria } \\
\text { nimbaria } \\
\text { L. alatus } \\
\text { Myctophum } \\
\text { asperum }\end{array}$ & \\
\hline F & $\begin{array}{l}81 \% \\
\text { E. australis } \\
\text { Diaphus spp. } \\
\text { (slender) }^{\mathrm{F}} \\
\text { Benthosema } \\
\text { fibulatum }^{\mathrm{F}}\end{array}$ & $\begin{array}{l}78 \% \\
\text { B. } \text { fibulatum }^{\mathrm{F}} \\
\text { S. } \text { sagax }^{\mathrm{B}} \\
\text { Bregmaceros spp. } \\
\text { Type } \mathrm{II}^{\mathrm{F}}\end{array}$ & $\begin{array}{l}53 \% \\
\text { B. fibulatum }\end{array}$ & $\begin{array}{l}66 \% \\
\text { B. fibulatum }\end{array}$ & $\begin{array}{l}64 \% \\
\text { B. fibulatum }\end{array}$ & $\begin{array}{l}48 \% \\
\text { Diaphus spp. } \\
\text { (slender) } \\
\text { B. fibulatum } \\
\text { Diaphus spp. } \\
\text { (deep) } \\
\text { L. alatus } \\
\text { V. nimbaria }\end{array}$ \\
\hline
\end{tabular}

blages was based primarily on the high abundance of Engraulis australis and Bregmaceros spp. (Type I) larvae but also on the high diversity of larvae of tropical neritic species and the much lower abundance of oceanic meso-pelagic taxa (Table 4). Assemblage B, representing inner shelf stations between $29^{\circ} \mathrm{S}$ and $34^{\circ} \mathrm{S}$, was delineated based upon the high abundance of $S$. sagax larvae as well as a generally lower abundance of meso-pelagic taxa compared with shelf-break and oceanic stations.

The correlation of larval fish assemblages with the available environmental variables using BVSTEP 

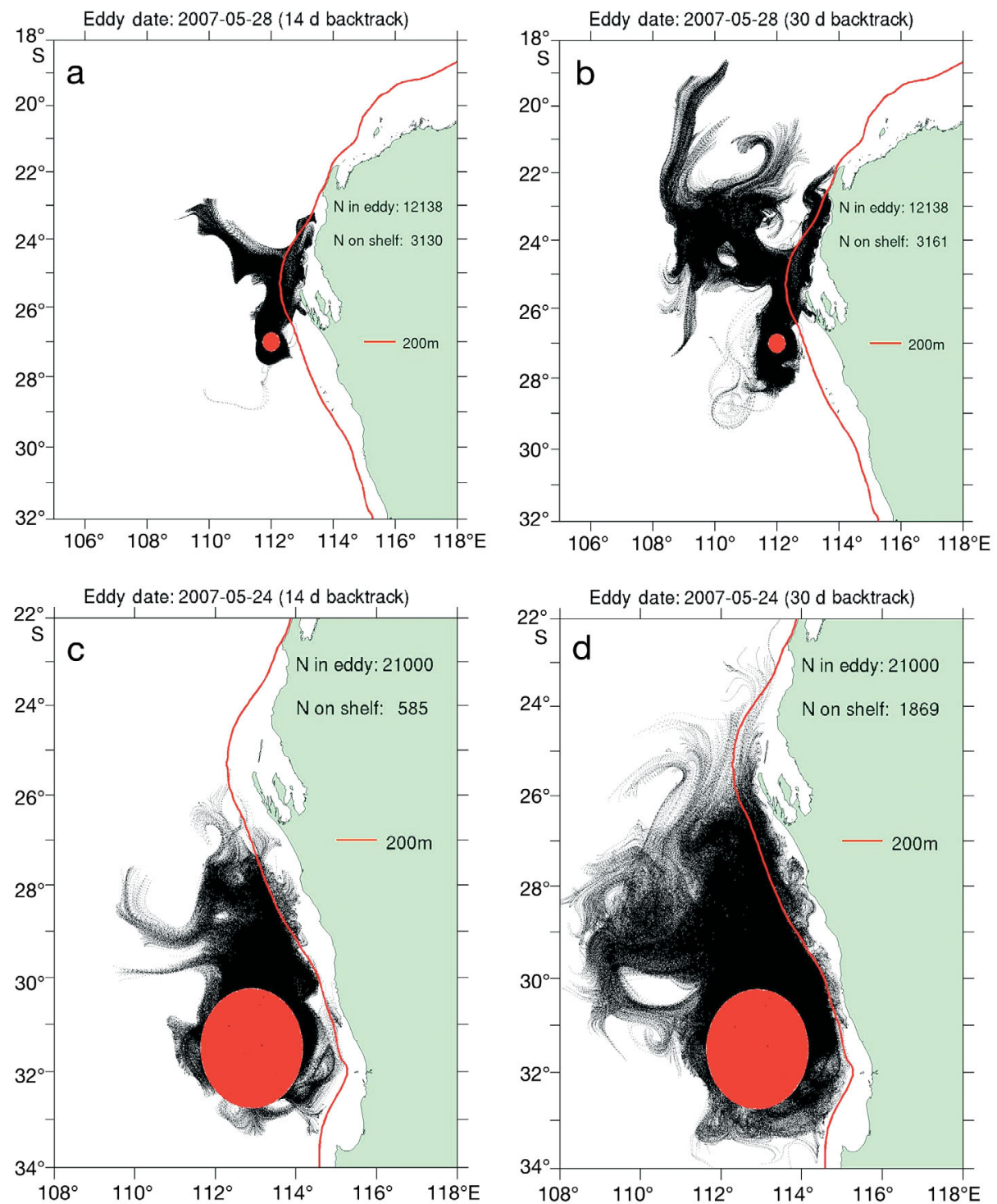

Fig. 10. Results of a Lagrangian particle back-tracking model showing the sources and pathways of particles entering 2 developing anticyclonic eddies (shown as red ellipses) located off the coast of Western Australia in late austral autumn, May 2007. The number of particles seeded in each eddy and those that interacted with the shelf are integrated for the water column between the surface and $200 \mathrm{~m}$ depth. $(\mathrm{a}, \mathrm{c})$ Particle tracks for $14 \mathrm{~d}$ after release; $(\mathrm{b}, \mathrm{d})$ particle tracks for $30 \mathrm{~d}$ after release

analysis returned a significant relationship with temperature (a surrogate for salinity and dissolved oxygen, i.e. water mass; $\rho=0.4, p=0.01$ ).

\section{Lagrangian particle tracking}

Trajectories from the Lagrangian particle backtracking revealed that the developing anticyclonic eddy offshore at $27^{\circ} \mathrm{S}$, which was characterised by a relatively high abundance of anchovy Engraulis australis larvae, had a strong connection with shelf waters (Fig. 10a,b) particularly within the upper $100 \mathrm{~m}$ of the water column during the first $14 \mathrm{~d}$ of release (Table 5). The connection was greatest for the $0-20 \mathrm{~m}$ depth stratum and $>80 \%$ of particles backtracked from this station had crossed the $200 \mathrm{~m}$ isobath during the previous $14 \mathrm{~d}$. Interestingly, there was little change in the number of particles interacting with the shelf between 14 and $30 \mathrm{~d}$. Connectivity between shelf and oceanic waters was substantially lower at depths $>100 \mathrm{~m}$. Fig. 10b shows that at a temporal scale of $30 \mathrm{~d}$, which is roughly the length of the pelagic larval stage of most marine teleosts (Leis 
1991), particles that interacted with the continental shelf before reaching the station were sourced from as far north as Northwest Cape at $\sim 22^{\circ} \mathrm{S}$.

Comparatively fewer particles that were seeded within the eddy located at $\sim 31^{\circ} \mathrm{S}$ had encountered continental shelf waters during the initial $14 \mathrm{~d}$ after release. (Fig. 10c, Table 5). Only $18 \%$ of particles in the 0-20 m depth stratum had crossed the $200 \mathrm{~m}$ isobath during this time. Within $30 \mathrm{~d}$ of release, $238 \%$ of particles interacted with the shelf in this depth stratum. This eddy tended to draw waters from a more southern section of the shelf between $26^{\circ} \mathrm{S}$ and $29^{\circ} \mathrm{S}$ as well as from the surrounding ocean (Fig. 10d). In this eddy, all except the deepest depth strata showed some connection with the shelf.

\section{DISCUSSION}

In the late austral autumn (May 2007) off the Western Australian coast, the Leeuwin Current was highly energetic and characterised by strong meandering

Table 5. Results of a 3-dimensional Lagrangian particle back-tracking model indicating the number of particles seeded and the number and percentage of particles that interacted with the shelf, per depth stratum, for 2 anticyclonic eddies off Western Australia in the late austral autumn, May 2007. The analysis is split to show the number of particles that had interacted with the shelf at 14 and $30 \mathrm{~d}$ after release

\begin{tabular}{|c|c|c|c|c|c|}
\hline \multirow{2}{*}{$\begin{array}{l}\text { Depth } \\
\text { (m) }\end{array}$} & \multirow{2}{*}{$\begin{array}{c}\text { No. } \\
\text { (seeded) }\end{array}$} & \multicolumn{2}{|c|}{$-14 \mathrm{~d}-$} & \multicolumn{2}{|c|}{$-30 \mathrm{~d}-$} \\
\hline & & $\begin{array}{c}\text { No. } \\
\text { (shelf) }\end{array}$ & $\%$ & $\begin{array}{l}\text { No. } \\
\text { (shelf) }\end{array}$ & $\%$ \\
\hline \multicolumn{6}{|c|}{ Eddy at $27^{\circ} \mathrm{S}$} \\
\hline $0-20$ & 1734 & 1407 & 81.1 & 1414 & 81.5 \\
\hline $20-40$ & 1156 & 512 & 44.3 & 522 & 45.2 \\
\hline $40-60$ & 1156 & 380 & 32.9 & 385 & 33.3 \\
\hline $60-80$ & 1156 & 368 & 31.8 & 371 & 32.1 \\
\hline $80-100$ & 1156 & 278 & 24.0 & 281 & 24.3 \\
\hline $100-120$ & 1156 & 158 & 13.7 & 158 & 13.7 \\
\hline $120-140$ & 1156 & 15 & 1.3 & 18 & 1.6 \\
\hline $140-160$ & 1156 & 12 & 1.0 & 12 & 1.0 \\
\hline $160-180$ & 1156 & 0 & 0.0 & 0 & 0.0 \\
\hline $180-200$ & 1156 & 0 & 0.0 & 0 & 0.0 \\
\hline \multicolumn{6}{|c|}{ Eddy at $32^{\circ} \mathrm{S}$} \\
\hline $0-20$ & 3000 & 546 & 18.2 & 1136 & 37.9 \\
\hline $20-40$ & 2000 & 13 & 0.7 & 106 & 5.3 \\
\hline $40-60$ & 2000 & 4 & 0.2 & 121 & 6.1 \\
\hline $60-80$ & 2000 & 5 & 0.3 & 181 & 9.1 \\
\hline $80-100$ & 2000 & 4 & 0.2 & 122 & 6.1 \\
\hline $100-120$ & 2000 & 8 & 0.4 & 98 & 4.9 \\
\hline $120-140$ & 2000 & 3 & 0.2 & 44 & 2.2 \\
\hline $140-160$ & 2000 & 1 & 0.1 & 33 & 1.7 \\
\hline $160-180$ & 2000 & 1 & 0.1 & 24 & 1.2 \\
\hline $180-200$ & 2000 & 0 & 0.0 & 4 & 0.2 \\
\hline
\end{tabular}

and numerous mesoscale features, including a developing anticyclonic eddy at $27^{\circ} \mathrm{S}$ and an older anticyclonic eddy at $\sim 31^{\circ} \mathrm{S}$. The Leeuwin Current was regionally pervasive and experienced sustained modification of its physical and chemical properties that was due, in part, to mixing with shelf waters (Thompson et al. 2011, Weller et al. 2011). Net transport by the Leeuwin Current is in the longshore direction and, like the Agulhas (Beckley 1998) and East Australian (Booth et al. 2007) Currents, it is responsible for the expatriation of tropical fishes to higher latitudes (Hutchins \& Pearce 1994, Pearce et al. 2006). However, recent modelling and empirical studies have highlighted cross-shelf variability in Leeuwin Current circulation, which is locally enhanced because of its mesoscale variability (Feng et al. 2010, Condie et al. 2011, Weller et al. 2011), thereby disrupting its southwards trajectory. As shown for other boundary currents including the Gulf Stream (Hare et al. 2001), Agulhas (Beckley 1998) and Kuroshio Currents (Okazaki \& Nakata 2007), variability of Leeuwin Current circulation has implications for the transport of planktonic biota and is demonstrated in this study by the distributions of larval fishes in the region, which are useful biological tracers of circulation and mixing between different water masses (Holliday et al. 2011).

The onshore and offshore distributions of larvae of oceanic meso-pelagic and neritic fishes, respectively, demonstrate the connectivity between inner shelf and oceanic waters and support the hypothesis that cross-shelf transport of planktonic biota occurs in the austral autumn in response to mesoscale variability of the Leeuwin Current. Specifically, these results support those of Feng et al. (2010), who suggested that dispersal of shelf waters and constituent planktonic biota is enhanced in regions of eddy formation. Conversely, in summer, there was greater delineation between larval fish assemblages over the shelf and offshore off southwestern Australia under conditions of a weakened Leeuwin Current and no eddies (Muhling et al. 2008).

The greater abundance of oceanic meso-pelagic larvae, particularly the myctophid Diaphus spp. (slender morphotype), over the inner shelf within the eddy field off southwestern Australia contrasted with the lower abundance of these larvae at lower latitudes. This may represent either greater onshore dispersal because of stronger onshore transport and/or mixing within the eddy field or simply a greater abundance of these larvae at higher latitudes in general. Oceanographic processes resulting in the onshore transport of Myctophidae larvae has been re- 
ported elsewhere, including the Agulhas Current in the southwestern Indian Ocean (Olivar \& Beckley 1994) and for the Mediterranean Sea (Sabatés \& Masó 1992).

The anticyclonic eddies at $27^{\circ} \mathrm{S}$ and $31^{\circ} \mathrm{S}$ were characterised by the occurrence of the larvae of tropical coastal and reef-associated fishes up to $\sim 200$ and $\sim 375 \mathrm{~km}$ offshore of the coast, respectively. Although most of these taxa occurred in very low abundances $\left(<1\right.$ larva $\left.\mathrm{m}^{-2}\right)$, their distribution at such large distances offshore points to the Leeuwin Current as a primary transport route for their incorporation into these eddies, as reported by Holliday et al. (2011). Elsewhere, the larvae of coral reef and other neritic fishes are incorporated into boundary current eddies in abundances that significantly affect recruitment variability in these populations (e.g. Flierl \& Wroblewski 1985, Graber \& Limouzy-Paris 1997, Sponaugle et al. 2005). The Leeuwin Current is recognized as having an important, but as yet undefined influence upon marine populations off Western Australia (Lenanton et al. 1991, Caputi et al. 1996, Griffin et al. 2001).

Condie et al. (2011) reported that the magnitude of offshore transport off Western Australia is lower in comparison to other boundary current systems because of inhibition by the Leeuwin Current. Yet the distributions of larval fishes from the present study and those of Muhling et al. (2008) and Holliday et al. (2011) suggest that shelf-ocean exchange of water and constituent planktonic biota in the austral autumn and winter is of significance. Greater mean onshore transport within the Leeuwin Current system is supported by the greater abundance of oceanic mesopelagic larvae over the shelf compared with the offshore occurrence of neritic fishes, although this might simply be due to there being fewer neritic larvae occurring at this time of year off Western Australia. Empirical data presented by Weller et al. (2011) showed that, during the present study, onshore transport was enhanced in association with jetlike structures in the upper $200 \mathrm{~m}$ of the water column, whilst the presence of eddies in the vicinity of the shelf break generated offshore transport. Elsewhere, the proximity of eddies to the shelf break is an important mechanism for the offshore advection of fish larvae, transporting them from spawning areas to nursery grounds (e.g. Cowen et al. 1993, Hare et al. 2001, Okazaki \& Nakata 2007). Conversely, off Western Australia, where the spawning locations of most neritic teleost species are unknown, ascertaining the importance of eddy-induced transport of larvae is difficult to resolve. Because eddies occur dur- ing the late austral autumn and winter off Western Australia, it is assumed that processes other than eddies are important in driving recruitment variability in populations that spawn during the spring and summer months.

During the present study, the Leeuwin Current was generally situated at or seaward of the shelf break (Thompson et al. 2011, Weller et al. 2011) and there was strong similarity between the shelf-break and oceanic larval fish assemblages along the entire surveyed coastline. This is considered to be a reflection of mixing at the shelf break between Leeuwin Current and oceanic sub-tropical waters. Norcross et al. (2003) reported the preferential concentration of larval fishes at the shelf break for the central North Pacific and, similarly, the present study recorded a significantly higher mean abundance of larval fish at this location. Muhling et al. (2008) reported a similar trend for larval fish assemblages between outer shelf and oceanic waters off southwestern Australia in winter in association with the Leeuwin Current. The higher abundance of larval fishes at the shelf break and the mix of oceanic meso-pelagic and neritic taxa suggest that the Leeuwin Current is an important mechanism concentrating fish larvae at this location. Unlike most studies that document the incorporation of zooplankton and larval fishes into mature eddies (e.g. Kasai et al. 2002, Mackas et al. 2005), the present study, coupled with those of Holliday et al. (2011) and Weller et al. (2011) demonstrates the incorporation of regional oceanic and shelf water masses and constituent planktonic biota into the Leeuwin Current along its trajectory, which then circulates into anticyclonic eddies during their formative stages.

Enhanced cross-shelf mixing is reflected in a homogeneous water mass and corresponding mixed larval fish assemblage, as shown for the California and East Australian Currents (Franco-Gordo et al. 2002, Keane \& Neira 2008, respectively). Off southwestern Australia $\left(30^{\circ} \mathrm{S}-34^{\circ} \mathrm{S}\right)$, shelf and oceanic waters were characterised by a single larval fish assemblage that reflected mixing between Leeuwin Current, shelf and oceanic waters. Conversely, at lower latitudes, there was a clear delineation between larval fish assemblages over the inner shelf from those at the shelf break and in oceanic waters, with the exception of the oceanic station at $27^{\circ} \mathrm{S}$. In general, spatial structuring of larval fish assemblages over continental shelves is often attributed to the existence of frontal structures, which act as physical barriers that prevent dispersal (e.g. Grothues \& Cowen 1999, Hare et al. 2001, Sabatés et al. 2004, Keane \& Neira 2008, Muhling et al. 2008). However, 
during the present study, shelf waters were well mixed and there were no obvious strong frontal features (Weller et al. 2011). Yet the Leeuwin Current was much less pervasive over the shelf at lower latitudes $\left(23^{\circ} \mathrm{S}-27^{\circ} \mathrm{S}\right)$ because of its lower velocity (Weller et al. 2011). If onshore incursions of the current are a primary mechanism driving cross-shelf exchange, as indicated by Feng et al. (2010), then this might explain the retention of larvae of neritic fishes over the inner shelf in this region of the Western Australian continental shelf. Comparatively, velocity and eddy kinetic energy of the Leeuwin Current is stronger south of $28^{\circ} \mathrm{S}$ and induces stronger cross-shelf exchange off southwestern Australia (Feng et al. 2010).

The distribution of larval fishes supports the results of Lagrangian particle back-tracking, which revealed strong coupling between shelf water and the 2 anticyclonic eddies at $27^{\circ} \mathrm{S}$ and $31^{\circ} \mathrm{S}$. At a temporal scale of $30 \mathrm{~d}$, equivalent to the pelagic larval duration of most teleosts (Leis 1991), the developing eddy at $27^{\circ} \mathrm{S}$ had a strong connection with shelf waters within the upper $100 \mathrm{~m}$ of the water column. In fact, most particles were transported from the shelf within the first $14 \mathrm{~d}$ and this corresponds well with the very high abundance of early developmental stage ( $<2 \mathrm{wk}$ old $)$ Engraulis australis larvae in the eddy. This eddy was also characterised by the occurrence of a number of early-stage larvae of tropical neritic vagrants $\left(<1\right.$ larva $\mathrm{m}^{-2}$ ). There was no significant difference in mean larval size of $E$. australis between the inner shelf and the eddy at $27^{\circ} \mathrm{S}$, suggesting continuous connection between these waters at the time of the study. Particle tracking demonstrated that anchovy larvae, and those of other neritic fishes, were transported via the Leeuwin Current and incorporated in the eddy, and that these larvae could have been sourced from as far afield as the inner shelf at $22^{\circ} \mathrm{S}$. The preferential distribution of clupeiform larvae in near-surface waters (Muhling \& Beckley 2007) suggests their susceptibility to Ekman transport; however, the wind field up to 1 mo prior to sampling did not support this type of advective transport (Weller et al. 2011).

In contrast, the eddy at $31^{\circ} \mathrm{S}$ was older in its development and, although having a number of neritic vagrants at its perimeter, the particle tracking showed less recent connection with continental shelf water. This eddy tended to draw more water from the surrounding ocean and, if typical of eddies in this region, this might explain the high abundance of oceanic meso-pelagic larvae in another developing anticyclonic eddy at this location reported by Holli- day et al. (2011). In their study of larval fish assemblages in eddies for the Gulf of Alaska, Atwood et al. (2010) showed that the assemblages were dynamic, changing as the eddies aged. It is therefore probable that the eddy at $31^{\circ} \mathrm{S}$ was characterised by a different larval fish assemblage in the period leading up to sampling, one that probably included more abundant and, perhaps, diverse neritic larvae.

Typically, larvae characterised as having longer pelagic larval durations, such as labrids (Victor 1986, 1987), are expected to disperse over greater distances. The width of the continental shelf off Western Australia is quite variable, yet the inshore and offshore occurrence of early-stage ( $<2 \mathrm{wk}$ old) larvae of oceanic meso-pelagic and neritic fish taxa, respectively, is indicative of the rate of cross-shelf transport. Given an average shelf width of around $87 \mathrm{~km}$, this equates to a transport rate across the shelf of approximately $0.1 \mathrm{~m} \mathrm{~s}^{-1}$, which is consistent with previous estimates of cross-shelf current velocities reported by Pearce et al. (2006). We do, however, expect that rates of cross-shelf transport are higher at certain areas along the Western Australian coast where the Leeuwin Current makes significant incursions over the shelf in association mesoscale eddies, such as off southwestern Australia. Furthermore, the generation of anticyclonic eddies is seasonally recurrent at locations along the continental shelf (Meuleners et al. 2007, Rennie et al. 2007), and these regions have been shown to experience greater offshore dispersal of shelf waters (Feng et al. 2010). The oceanic occurrence of neritic larvae corresponded well with the areas of low retention described by Feng et al. (2010), for example at $27^{\circ} \mathrm{S}$ and $30^{\circ} \mathrm{S}$, which experience seasonal eddy formation in the austral autumn-winter.

Advection in the alongshore direction was evident from the distributions of larvae of some tropical neritic taxa at higher latitudes, particularly the occurrence of these larvae at the perimeter of the anticyclonic eddy at $31^{\circ} \mathrm{S}$. However, because of a lack of adequate taxonomic descriptions, most larvae of tropical neritic fishes could not be identified to species level. Because the source of these larvae, i.e. the location at which they were spawned, could not be ascertained, their distributions could not be used as indicators to accurately resolve the scale of alongshore transport, particularly at lower latitudes between $22^{\circ} \mathrm{S}$ and $29^{\circ} \mathrm{S}$.

From modelling studies, Feng et al. (2010) and Condie et al. (2011) indicated that shelf waters in proximity to the Abrolhos Islands at $29^{\circ} \mathrm{S}$ off the Western Australia coast are characterised by high retention. The present study found an obvious delin- 
eation in the diversity and abundance of larvae of coastal neritic taxa at $29^{\circ} \mathrm{S}$, i.e. higher at lower latitudes, as well as reduced transport of these larvae south of this latitude at the shelf break. These trends in larval dispersal reflect well the known biogeography of adult fish populations off Western Australia. Specifically, there is a distinct latitudinal change from a species-rich, tropical Indo-Pacific assemblage to a smaller suite of temperate species, many of which are endemic, south of the Abrolhos Islands at $29^{\circ} \mathrm{S}$ (Fox \& Beckley 2005). In their study of transport of ichthyoplankton in the Benguela Current system, Lett et al. (2007) concluded that, in the absence of any physical barrier to alongshore dispersal, environmental properties such as lower ambient water temperatures at higher latitudes limited northwards dispersal because of increased mortality. Likewise, Keane \& Neira (2008) ascribed a decrease in the number of tropical neritic taxa southward along the southeastern Australia coast to environmental conditions. The same may be true for Western Australia, although the southward extension of warm Leeuwin Current water allows the growth of high-latitude corals and associated fish fauna off Rottnest Island located at $\sim 32^{\circ} \mathrm{S}$ off southwestern Western Australia (Hutchins \& Pearce 1994).

The particle back-tracking model corresponded well with empirical data of larval fish assemblages sampled within 2 developing eddies and demonstrated the potential for broad-scale advection of planktonic biota both across the shelf and alongshore. However, the data-assimilating nature of BRAN distorts the evolution of the flow field and causes an inaccuracy in the particle tracking. We assume that the distortion is distributed such that the particle-tracking model approximates a random walk effect. Furthermore, the model uses passive particles, whereas the larvae of marine fishes are equipped with complex behavioral and physiological capabilities that can influence their transport (swimming or changing position in the water column) (Leis 2002, 2006). Therefore, we would not expect the results of the Lagrangian particle tracking to be entirely supported by the empirical distributions of larval fishes. Also, this model is currently unable to adequately resolve circulation over the inner shelf. It will be important to examine coastal circulation during the austral autumn and winter to determine the mechanisms that favour the retention of most larvae of coastal teleosts in these waters at lower latitudes.

This study, using empirical and modelled data, provides insight into an eastern Indian Ocean boundary current, demonstrating the importance of mesoscale variability of the Leeuwin Current to the transport and fate of planktonic biota. Coupled with the findings of Weller et al. (2011), the present study shows that cross-shelf transport can be equally as important in the otherwise alongshore-dominated system of the Leeuwin Current.

Acknowledgements. This research was made possible with funding support from the Marine National Facility (MNF) for vessel time and the Commonwealth Scientific and Industrial Research Organization (CSIRO) Wealth from Oceans Flagship. D.H. was supported by a Murdoch University PhD scholarship and funding from the Western Australian Marine Science Institution (WAMSI). International travel for M.P.O. was funded by WAMSI and Murdoch University. We thank the officers, crew and scientific complement of the RV 'Southern Surveyor' for their contributions during the voyage.

\section{LITERATURE CITED}

Anderson MJ (2005) PERMANOVA: a FORTRAN computer program for permutational multivariate analysis of variance. Department of Statistics, University of Auckland

$>$ Atwood E, Duffy-Anderson JT, Horne JK, Ladd C (2010) Influence of mesoscale eddies on ichthyoplankton assemblages in the Gulf of Alaska. Fish Oceanogr 19:493-507

Auth TD (2008) Distribution and community structure of ichthyoplankton from the northern and central California Current in May 2004-06. Fish Oceanogr 17:316-331

Beckley LE (1998) The Agulhas Current ecosystem with particular reference to dispersal of fish larvae. In: Sherman K, Okemwa EN, Nitiba MJ (eds) Large marine ecosystems of the Indian Ocean: assessment, sustainability and management. Blackwell Science, Malden, MA, p 255-277

> Beckley LE, Van Ballegooyen RC (1992) Oceanographic conditions during three ichthyoplankton surveys of the Agulhas Current in 1990/91. S Afr J Mar Sci 12:83-93

> Booth DJ, Figueira WF, Gregson MA, Brown L, Beretta G (2007) Occurrence of tropical fishes in temperate southeastern Australia: role of the East Australian Current. Estuar Coast Shelf Sci 72:102-114

> Caputi N (2008) Impact of the Leeuwin Current on the spatial distribution of the puerulus settlement of the western rock lobster (Panulirus cygnus) and implications for the fishery of Western Australia. Fish Oceanogr 17:147-152

Caputi N, Fletcher WJ, Pearce AF, Chubb CF (1996) Effect of the Leeuwin Current on the recruitment of fish and invertebrates along the Western Australian coast. Mar Freshw Res 47:147-155

Clarke KR, Warwick RM (2005) Primer-6 computer program. Natural Environment Research Council, Plymouth

Condie SA, Mansbridge JV, Cahill ML (2011) Contrasting local retention and cross-shelf transports of the East Australian Current and the Leeuwin Current and their relative influences on the life histories of small pelagic fishes. Deep-Sea Res II 58:606-615

Cowen RK (2002) Oceanographic influences on larval dispersal and retention and their consequences for population connectivity. In: Sale PF (ed) Coral reef fishes: dynamics and diversity in a complex ecosystem. Academic 
Press, San Diego, CA, p 149-170

Cowen RK, Hare JA, Fahay MP (1993) Beyond hydrography: Can physical processes explain larval fish assemblages within the middle Atlantic Bight? Bull Mar Sci 53: 567-587

Csanady GT (1997) On the theories that underlie our understanding of continental shelf circulation. J Oceanogr 53: 207-229

Feng M, Meyers G, Pearce A, Wijfels S (2003) Annual and interannual variations of the Leeuwin Current at $32^{\circ} \mathrm{S}$. J Geophys Res 108:3355 doi:10.1029/2002JC001763

> Feng M, Majewski L, Fandry CB, Waite AM (2007) Characteristics of two counter-rotating eddies in the Leeuwin Current system off the Western Australian coast. DeepSea Res II 54:961-980

Feng M, Slawinski D, Beckley LE, Keesing JK (2010) Retention and dispersal of shelf waters influenced by interactions of ocean boundary current and coastal geography. Mar Freshw Res 61:1259-1267

Flierl GR, Wroblewski JS (1985) The possible influence of warm core Gulf Stream rings upon shelf water larval fish distribution. Fish Bull 88:313-330

- Fox NJ, Beckley LE (2005) Priority areas for conservation of Western Australian coastal fishes: a comparison of hotspot, biogeographical and complementarity approaches. Biol Conserv 125:399-410

> Franco BC, Muelbert JH, Mata MM (2006) Mesoscale physical processes and the distribution and composition of ichthyoplankton on the southern Brazilian shelf break. Fish Oceanogr 15:37-43

- Franco-Gordo C, Godinez-Dominguez E, Suarez-Morales E (2002) Larval fish assemblages in the waters off the central Pacific coast of Mexico. J Plankton Res 24:775-784

Graber HC, Limouzy-Paris CB (1997) Transport patterns of tropical reef fish larvae by spin-off eddies in the Straits of Florida. Oceanography 10:68-71

Griffin DA, Wilkin JL, Chubb CF, Pearce AF, Caputi N (2001) Ocean currents and the larval phase of Australian western rock lobster, Panulirus cygnus. Mar Freshw Res 52:1187-1199

- Grothues TM, Cowen R (1999) Larval fish assemblages and water mass history in a major faunal transition zone. Cont Shelf Res 19:1171-1198

Hare JA, Govoni JJ (2005) Comparison of average larval fish vertical distributions among species exhibiting different transport pathways on the southeast United States continental shelf. Fish Bull 103:729-736

> Hare JA, Quinlan JA, Werner FE, Blanton BO and others (1999) Larval transport during winter in the SABRE study area: results of a coupled vertical larval behaviour-threedimensional circulation model. Fish Oceanogr 8:57-76

- Hare JA, Fahay MP, Cowen R (2001) Springtime ichthyoplankton of the slope region off the north-eastern United States of America: larval assemblages, relation to hydrography and implications for larval transport. Fish Oceanogr 10:164-192

Hare JA, Chruchill JH, Cowen RK, Berger TJ and others (2002) Routes and rates of larval fish transport from the southeast to the northeast United States continental shelf. Limnol Oceanogr 47:1774-1789

> Holliday D, Beckley LE, Olivar MP (2011) Incorporation of larval fishes into a developing anti-cyclonic eddy of the Leeuwin Current off south-western Australia. J Plankton Res 33:1696-1708

Hutchins B, Pearce AF (1994) Influence of the Leeuwin Cur- rent on recruitment of tropical reef fishes at Rottnest Island, Western Australia. Bull Mar Sci 54:245-255

John H, Mohrholz V, Lutjeharms JRE (2001) Cross-front hydrography and fish larval distribution at the AngolaBenguela Frontal Zone. J Mar Syst 28:91-111

Kasai A, Kimura S, Nakata H, Okazaki Y (2002) Entrainment of coastal water into a frontal eddy of the Kuroshio, and its biological significance. J Mar Syst 37:185-198

Keane JP, Neira FJ (2008) Larval fish assemblages along the south-eastern Australian shelf: linking meso-scale nondepth-discriminate structure and water masses. Fish Oceanogr 17:263-280

Lanksbury JA, Duffy-Anderson JT, Mier KL, Wilson MT (2005) Ichthyoplankton abundance, distribution and assemblage structure in the Gulf of Alaska during September 2000 and 2001. Estuar Coast Shelf Sci 64:775-785

> Leis JM (1991) Vertical distribution of fish larvae in the Great Barrier Reef Lagoon, Australia. Mar Biol 109: $157-166$

> Leis JM (2002) Pacific coral-reef fishes: the implications of behaviour and ecology of larvae for biodiversity and conservation, and a reassessment of the open population paradigm. Environ Biol Fishes 65:199-208

Leis JM (2006) Are the larvae of demersal fishes plankton or nekton? Adv Mar Biol 51:59-141

Leis JM, Carson-Ewart BM (eds) (2000) The larvae of IndoPacific coastal fishes: a guide to identification. Brill, Leiden

Lenanton RC, Joll L, Penn J, Jones K (1991) The influence of the Leeuwin Current on coastal fisheries of Western Australia. J R Soc West Aust 74:101-114

Lett C, Veitch J, van der Lingen CD, Hutchings L (2007) Assessment of an environmental barrier to transport of ichthyoplankton from the southern to northern Benguela ecosystems. Mar Ecol Prog Ser 347:247-259

Levitus S (1982) Climatological atlas of the world ocean, NOAA Prof Pap 13, US Government Printing Office, Washington, DC

Mackas DL, Tsurumi M, Galbraith MD, Yelland DR (2005) Zooplankton distribution and dynamics in a North Pacific eddy of coastal origin: II. Mechanisms of eddy colonization by and retention of offshore species. Deep-Sea Res II 52:1011-1035

Meuleners MJ, Pattiaratchi CP, Ivey GN (2007) Numerical modelling of the mean flow characteristics of the Leeuwin Current System. Deep-Sea Res II 54:837-858

Moser HG, Richards WJ, Cohen DM, Fahay MP, Kendall AW, Richardson SL (eds) (1984) Ontogeny and systematics of fishes. Am Soc Ichthyol Herpetol Spec Publ 1. Allen Press, Lawrence, KS

Moser HG, Ahlstrom EH (1970) Development of laternfishes (family Myctophidae) in the California Current Part 1: species with narrow-eyed larvae. Bull Los Angeles City Mus Nat Hist 7:1-145

Moser HG, Watson W (2005) Myctophidae: Lanternfishes. In: Richards WJ (ed) Early stages of Atlantic fishes: an identification guide for the Western Central North Atlantic, Vol 1. Taylor \& Francis Boca Raton, FL, p 473-580

Muhling BA, Beckley LE (2007) Seasonal variation in horizontal and vertical structure of larval fish assemblages off south-western Australia, implications for larval transport. J Plankton Res 29:967-983

Muhling BA, Beckley LE, Koslow JA, Pearce AF (2008) Larval fish assemblages and water mass structure off the oligotrophic south-western Australian coast. Fish 
Oceanogr 17:16-31

Neira FJ, Misckiewicz AG, Trnski T (eds) (1998) Larvae of temperate Australian fishes. University of Western Australia Press, Perth

Norcross BL, McKinnell SM, Frandsen DL, Sweet SR (2003) Larval fishes in relation to water masses of the Central North Pacific transitional areas, including the shelf break of west-central Alaska. J Oceanogr 59:445-460

Okazaki Y, Nakata H (2007) Effect of mesoscale hydrographic features on larval fish distribution across the shelf break of East China Sea. Cont Shelf Res 27: 1616-1628

Oke PR, Brassington GB, Griffin DA, Schiller A (2008) The Bluelink ocean data assimilation system (BODAS). Ocean Model 21:46-70

Olivar MP, Beckley LE (1994) Influence of the Agulhas Current on the distribution of lanternfish larvae off the southeast coast of Africa. J Plankton Res 16:1759-1780

Olivar MP, Fortuño JM (1991) Guide to ichthyoplankton of the Southeast Atlantic (Benguela Current region). Sci Mar 55:1-383

Olivar MP, Moser HG, Beckley LE (1999) Lanternfish larvae from the Agulhas current (SW Indian Ocean). Sci Mar 63: 101-120

Pearce AF (1991) Eastern Boundary Currents of the Southern Hemisphere. J R Soc West Aust 74:35-45

> Pearce AF, Lynch MJ, Hanson CE (2006) The Hillarys Transect (1): seasonal and cross-shelf variability of the physical and chemical properties off Perth, Western Australia, 1996-98. Cont Shelf Res 26:1689-1729

Rennie SJ, Pattiaratchi CP, McAuley RD (2007) Eddy formation through the interaction between the Leeuwin Current, Leeuwin Undercurrent and topography. Deep-Sea Res II 54:818-836

Richards WJ (ed) (2006) Early stages of Atlantic fishes: an

Editorial responsibility: Paul Snelgrove, St. John's, Newfoundland and Labrador, Canada identification guide for the Western Central North Atlantic, Vol. 1. Taylor \& Francis, Boca Raton, FL

Ridgway KR, Condie SA (2004) The 5500-km-long boundary flow off western and southern Australia. J Geophys Res 109:C04017 doi:10.1029/2003JC001921

Sabatés A, Masó M (1992) Unusual larval fish distribution pattern in a coastal zone of the western Mediterranean. Limnol Oceanogr 37:1252-1260

Sabatés A, Salat J, Masó M (2004) Spatial heterogeneity of fish larvae across a meandering current in the northwestern Mediterranean. Deep-Sea Res II 51:545-557

Smith PE, Richardson SL (1977) Standard techniques for pelagic fish egg and larva surveys. FAO Fish Tech Pap 175:1-100

Sponaugle S, Lee T, Kourafalou V, Pinkard D (2005) Florida Current frontal eddies and the settlement of coral reef fishes. Limnol Oceanogr 50:1033-1048

Suthers IM, Everett JD, Roughan M, Young JW and others (2011) The strengthening East Australian Current, its eddies and biological effects - an introduction and overview. Deep-Sea Res II 58:538-546

Thompson PA, Wild-Allen K, Lourey M, Rousseaux C, Waite AM, Feng M, Beckley LE (2011) Nutrients in an oligotrophic boundary current: evidence of a new role of the Leeuwin Current. Prog Oceanogr 91:345-359

Victor BC (1986) Duration of the planktonic larval stage of one hundred species of Pacific and Atlantic wrasses (family Labridae). Mar Biol 90:317-326

Victor BC (1987) Growth, dispersal and identification of planktonic labrid and pomacentrid reef-fish larvae in the eastern Pacific Ocean. Mar Biol 95:145-152

Weller E, Holliday D, Feng M, Beckley L, Thompson P (2011) A continental shelf scale examination of the Leeuwin Current off Western Australia during the austral autumnwinter. Cont Shelf Res 31:1858-1868

Submitted: August 22, 2011; Accepted: March 21, 2012 Proofs received from author(s): July 4, 2012 